\title{
Conservation Status of the Georgia Blind Salamander (Eurycea wallacei) from the Floridan Aquifer of Florida and Georgia
}

Danté B. Fenolio ${ }^{1}$, Matthew L. Niemiller ${ }^{2}$, Michael G. Levy $^{3}$, and Benjamin Martinez ${ }^{4}$

${ }^{1}$ Department of Conservation Research, Atlanta Botanical Garden, Atlanta, Georgia 30309 USA (Current Address: Department of Conservation and Research, San Antonio Zoo, San Antonio, Texas 78212, USA) (dantefenolio@sazoo.org)

${ }^{2}$ Department of Ecology \& Evolutionary Biology, Yale University, New Haven, Connecticut 06520, USA (matthew.niemiller@yale.edu)

${ }^{3}$ Department of Population Health and Pathobiology, North Carolina State University College of Veterinary Medicine, Raleigh, North Carolina 27606, USA (mike_levy@ncsu.edu)

${ }^{4}$ National Speleological Society, Huntsville, Alabama 35810, USA (martinez2000@gmail.com)

Abstract.-The Georgia Blind Salamander (Eurycea wallacei) is a poorly understood stygobitic plethodontid salamander found in the Floridan Aquifer of Florida and Georgia, USA. Its distribution is poorly delimited and little information is available on the ecology and life history of the species. We summarize existing information on the Georgia Blind Salamander and report new findings with regard to distribution, conservation status, and aspects of its ecology and life history from recent surveys in Florida and Georgia, including anecdotal observations made by local cave divers. We also present data on the prevalence of Batrachochytrium dendrobatidis and discuss potential measures and challenges involved in conservation. Georgia Blind Salamanders are known from at least 35 localities within five United States Geological Survey (USGS) HUC8 watersheds in Florida and Georgia, all within the groundwater of the Upper Floridan Aquifer. Some populations may be large, as cave divers have observed $>100$ salamanders in a single dive at three localities and reported densities up to 10 salamanders per square meter. We confirm through direct observation that the Dougherty Plain Cave Crayfish (Cambarus cryptodytes) is a predator of E. wallacei. Although we found no evidence that any populations of the Georgia Blind Salamander have been infected by amphibian chytrid fungus, clear threats remain and include: (1) An "at risk" ranking by USGS of the Floridan Aquifer for contamination; (2) overharvesting of groundwater; (3) the 
presence of an emergent infectious amphibian disease in surface amphibians in the region (e.g., amphibian chytrid fungus); and (4) a lack of data on the basic biology and ecology of the species. We recommend the following conservation actions: (1) Better regulations and improved methods for retaining pesticide and fertilizer contaminants on the surface; (2) regulatory review of agricultural crops grown in the region and the establishment of systems and crops that do not require center pivot irrigation; (3) regular monitoring for disease across the range of the species; and (4) establishment of multiple assurance colonies such that captive specimens genetically represent at least half of the known populations.

Key Words: Eurycea wallacei; Georgia Blind Salamander; conservation; threats; groundwater fauna; amphibian; amphibian chytrid fungus; chytridiomycosis; Batrachochytrium dendrobatidis; captive breeding program; cave; distribution; Floridan Aquifer; Dougherty Plain; life history; Marianna Lowlands.

$\mathrm{T}_{\mathrm{s}}^{\mathrm{h}}$ he study of organisms that inhabit extreme environments can teach us about the adaptability of life in challenging conditions. Groundwater aquifers and other subterranean aquatic habitats are among the most extreme environs and are characterized by no light, complex mixes of gasses and chemicals, scarce nutrient sources, and, in some cases, low temperatures. Stygobites - obligate inhabitants of groundwater - are some of the least understood organisms and many species are of conservation concern because they have restricted distributions and humans have limited access to their subterranean haunts. Furthermore, little is known about the ecology and life history of most species, which hampers conservation efforts. This is particularly true for most of the 10 species of stygobitic salamanders (Goricki et al. 2012). However,

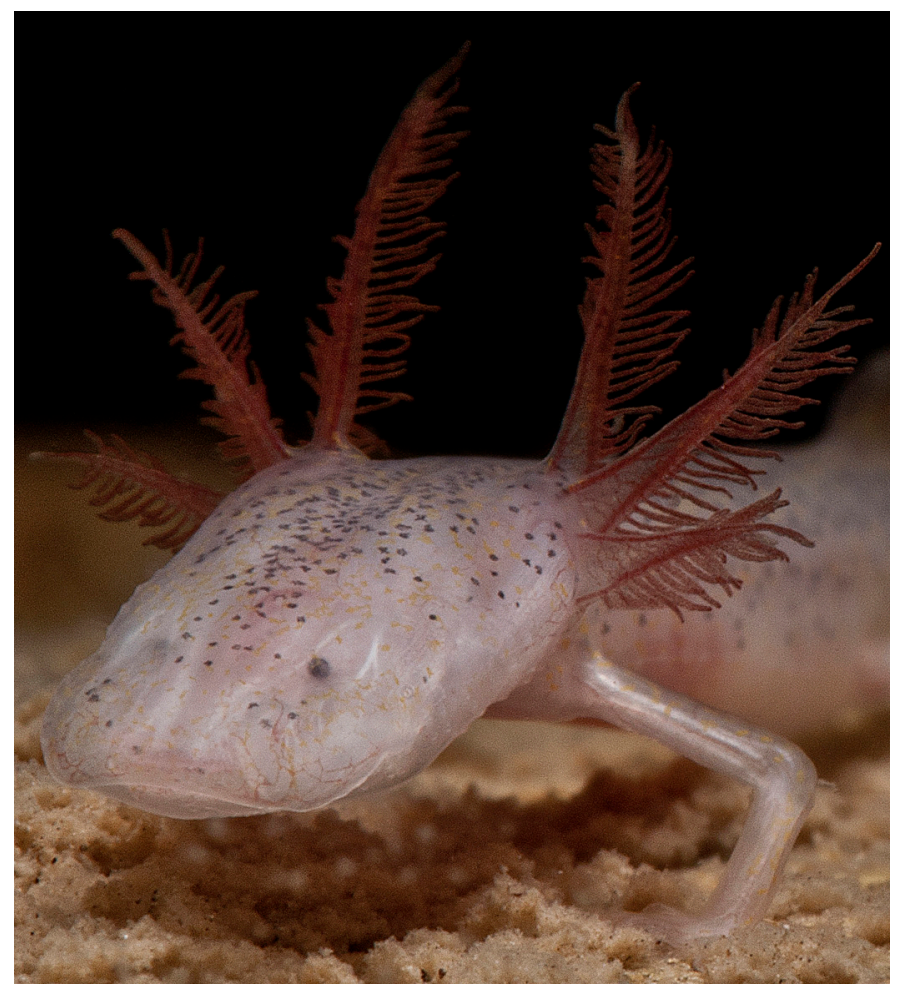

Fig. 1. The Georgia Blind Salamander (Eurycea wallacei) has a series of scattered chromatophores across its dorsal surface. Note the prominent external gills retained into adulthood. advancements in cave exploration equipment (particularly in light technology), collecting methods, and cave diving have allowed new opportunities in the study of stygobitic organisms. Here we report new findings on the ecology and life history of one of the least understood stygobitic salamanders, the Georgia Blind Salamander (Eurycea wallacei) (Figs. 1-3).

The Georgia Blind Salamander was described by Carr (1939) as Haideotriton wallacei based on a specimen taken from a 200-foot-deep well near Albany, Georgia. However, Frost et al. (2006) synonymized the genus Haideotriton with Eurycea based on analyses of molecular data. This neotenic species inhabits the Floridan Aquifer, which lies beneath southwestern Georgia, southeastern Alabama, and northwestern Florida in the Marianna Lowlands and the Dougherty Plain where artesian waters are contained in carbonate strata of the Ocala and Suwannee formations (Means 2005) (Fig. 4). Outside of inclusion in field guides and other species summaries without new data contributions, scant information has been published on the species' biology or ecology (Carr 1939; Pylka and Warren 1958; Dundee 1962; Valentine 1964; Brandon 1967; Lee 1969; Peck 1973; Means 1977, 1992, 2005; Brandt and Jackson 2003; Morris 2006; Goricki et al. 2012). Georgia Blind Salamanders have been reported from seven localities in Georgia (access to two have been destroyed) and 28 localities in northwestern Florida (Pylka and Warren 1958; Dundee 1962; Means 1977, 1992, 2005), including 22 in Jackson County, five in Washington County, and one in Calhoun County. However, the Florida Fish and Wildlife Conservation Commission only recognized three localities from Georgia (two in Dougherty County and one in Decatur County). These records include vadose caves, sinkholes, wells, and partially or completely submerged limestone cave systems (Pylka and Warren 1958; Dundee 1962; Means 1977, 1992, 2005). Georgia Blind Salamanders are at risk from several anthropogenic threats, the most serious of which are over-harvesting of groundwater and groundwater pollution (Means 1977, 1992, 2005). The species is listed as "Vulnerable" by IUCN (Hammerson 2004) and "Imperiled" (G2) by NatureServe (Natureserve 2013) because of few known occurrences, limited geographic distribution, 

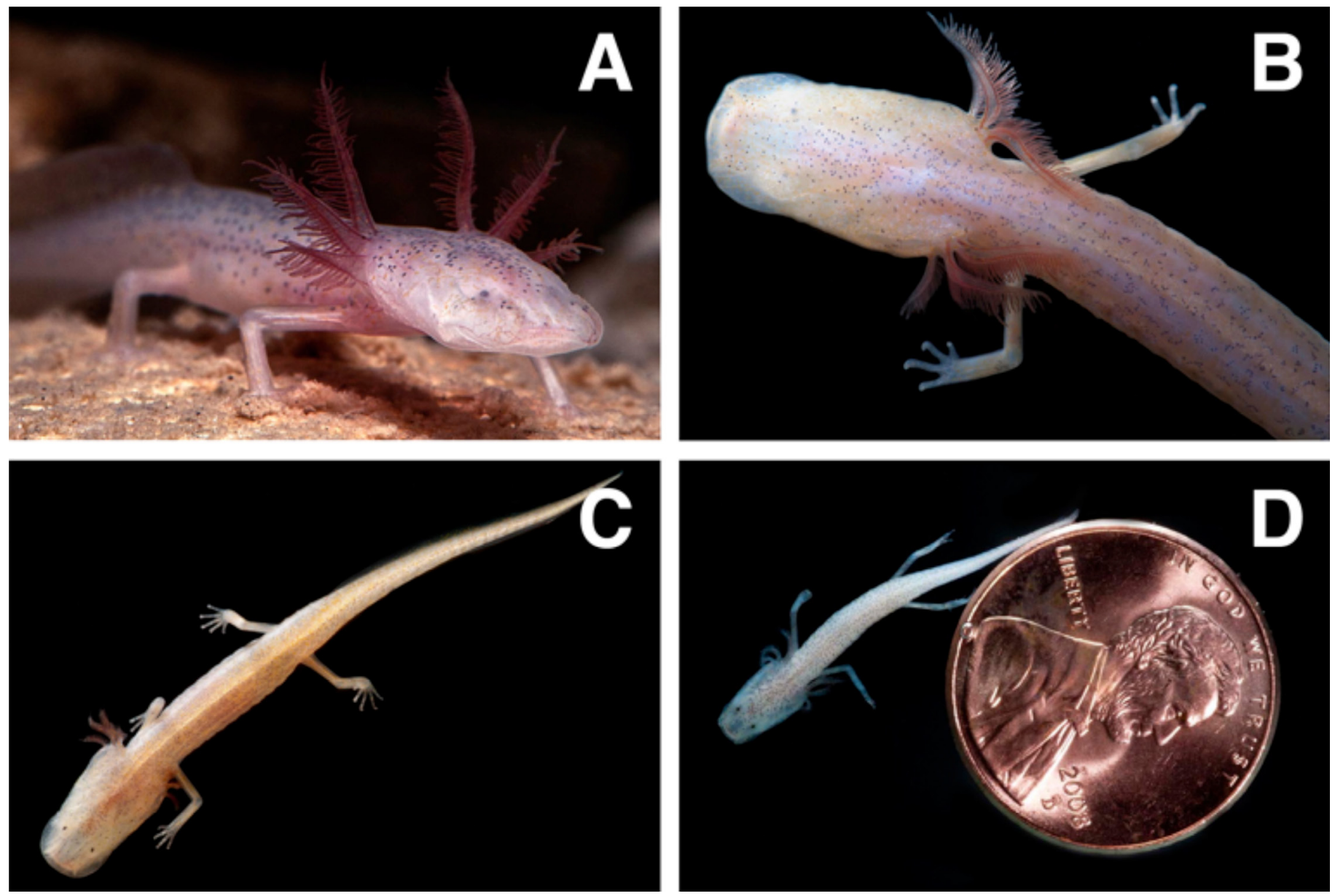

Fig. 2. The Georgia Blind Salamander (Eurycea wallacei) is a stygobitic and troglomorphic salamander in all regards: Eurycea wallacei is a neotenic species, reaching reproductive condition in the larval form (A). Only the faintest vestiges of eyes can be observed in some individuals as small dark lumps below the translucent skin of E. wallacei (B). The skin of E. wallacei is translucent and lacks significant pigmentation. Individual pigment cells can often be observed in the dermis (C). Juveniles have a well developed caudal fin (more than adults) and are only a few millimeters in total length (D); this individual (24 mm total length) is of unknown age but is likely just several months from hatching.

potential rangewide threats, and declines in range and population size. The Georgia Blind Salamander is also designated as "Threatened" in both Florida and Georgia (Means 2005, Jensen et al. 2008).

Given potentially increasing threats facing Georgia Blind Salamander populations and a lack of basic knowledge about the ecology and life history of the species, studies must be initiated to make accurate conservation assessments and employ appropriate conservation and management measures. Here, we summarize what is known regarding the distribution, ecology, life history, and conservation of the Georgia Blind Salamander. Then we present new data from recent surveys in Florida and Georgia, including anecdotal notes and observations made by local cave divers. We also present data on the prevalence of Batrachochytrium dendrobatidis $(B d)$ in $E$. wallacei. Lastly, we discuss the potential measures and challenges involved in the conservation of this enigmatic groundwater salamander.

\section{Methods}

We summarized information on the ecology and life history of the Georgia Blind Salamander contained in peerreviewed journals, species accounts in state and regional field guides, unpublished government reports, and our own studies. This information is limited because biologists have poor access to most subterranean waters inhabited by the species. Furthermore, because humans have better access to them, studies and observations on E. wallacei are primarily associated with subterranean pools and streams in vadose caves and sinkholes (Means 2005). However, knowledgeable cave divers can explore and survey significantly more aquatic habitat by diving springs and submerged cave systems connected to the Floridan Aquifer. Therefore, we interviewed five cave divers who regularly dive cave springs of the Floridan Aquifer in southwestern Georgia and northwestern Florida: Jim Clark, Kelly Jessop, Mike Stine, Bonnie Stine, and Edd Sorenson (author BM also is a cave diver). Specifically, we asked the 


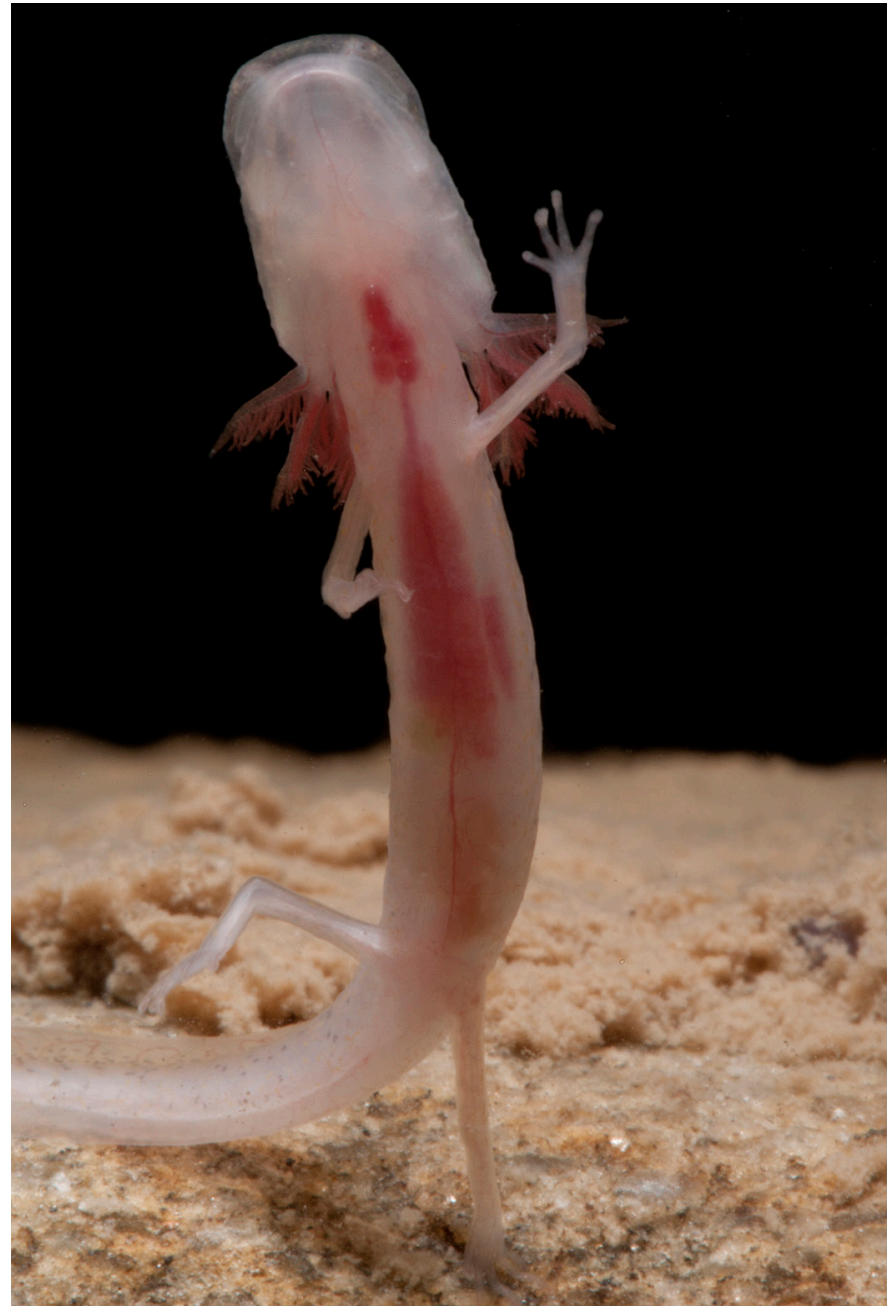

Fig. 3. Internal organs can be seen through the translucent ventral surface. The shovel-shaped head is clearly depicted from this angle.

divers when, where, and how many salamanders they have observed during recreational dives and to describe other observations regarding the species. These same cave divers have hand collected specimens for us using fish nets and slurp guns. The specimens were used to (1) collect tissue samples (tail tips) for a forthcoming genetic analysis, (2) collect skin swabs to survey for infectious disease, and (3) collect a limited number of specimens $(\mathrm{n}=12)$ for a captive colony (Fig. 5). We also queried the HerpNet online database (www.herpnet. org/) for museum accessions of the Georgia Blind Salamander from 56 participating institutions with herpetological collections searchable from the Internet.

Many recently documented amphibian declines are associated with the pathogenic fungus Batrachochytrium dendrobatidis or $B d$, which causes chytridiomycosis in amphibians (Longcore et al. 1999, Berger et al. 1998, Daszak et al. 2003, Lips et al. 2003, Muthsa et al. 2003, Mendelson et al. 2004, Rachowicz et al. 2006, Schloegel et al. 2006). Bd has not been implicated in declines of $E$. wallacei, but has been detected in populations of surface amphibians within the range of the Georgia Blind Salamander (P. Moler, pers. comm.). Therefore, this emergent infectious disease could threaten populations of $E$. wallacei. We collected non-invasive skin swabs from 41 Georgia Blind Salamanders in total from one population in Georgia and six populations in Florida (Table 1). We swabbed for $B d$ as follows. Individual salamanders were collected and gently swabbed using sterile polyester tipped applicators on the gular region, the flank region, the bottoms of the hands and feet, and along the venter for 12 passes per body region. When dry, the tips of the swabs were transferred to individual sterile tubes and stored at $4^{\circ} \mathrm{C}$ until extracted and assayed. The tip of the polyester applicator was transferred to a $2 \mathrm{ml}$ cryovial and $100 \mu \mathrm{l}$ of Prepman Ultra (Applied Biosystems, Foster City, California) was added followed by $50 \mathrm{mg}$ of $0.5 \mathrm{~mm}$ glass beads for extraction. The tubes were vortexed and homogenized for $1 \mathrm{~min}$ in a Mini BeadBeate (Biospec Products), then placed in boiling water for $10 \mathrm{~min}$, cooled for $1 \mathrm{~min}$ and centrifuged at 14,000 rpm for $3 \mathrm{~min}$. The liquid was then transferred using a micropi-

Table 1. Localities where Georgia Blind Salamanders were sampled and tested for amphibian chytrid fungus (Batrachochytrium dendrobaditis) in Florida and Georgia. Sixty-six salamanders were observed, of which 41 salamanders were sampled. No salamanders tested positive for Bd.

\begin{tabular}{lllll} 
Locality & County & State & No. observed & No. sampled \\
\hline Hole in the Wall Spring, Merritt's Mill Pond & Jackson & Florida & $10+$ & 5 \\
\hline Jackson Blue Spring, Merritt's Mill Pond & Jackson & Florida & $15+$ & 6 \\
\hline Black Hole Spring & Jackson & Florida & 7 & 5 \\
\hline Bozell Spring & Jackson & Florida & 6 & 5 \\
\hline Maunz Spring & Jackson & Florida & $15+$ & 10 \\
\hline Hidden Spring & Washington & Florida & 6 & 5 \\
\hline Radium Spring & Dougherty & Georgia & 7 & 5 \\
\hline
\end{tabular}




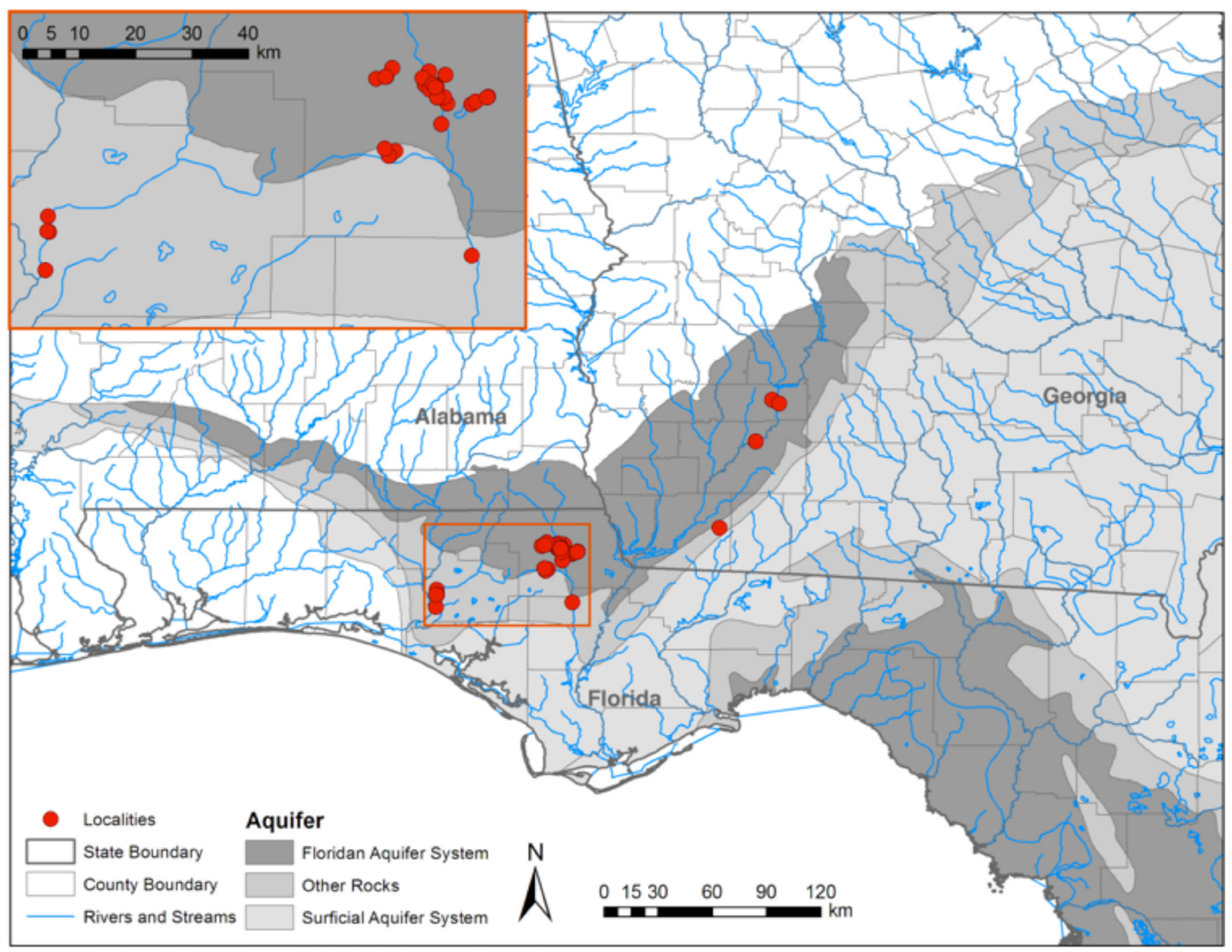

Fig. 4. Documented localities for the Georgia Blind Salamander (Eurycea wallacei) in the Floridan Aquifer.
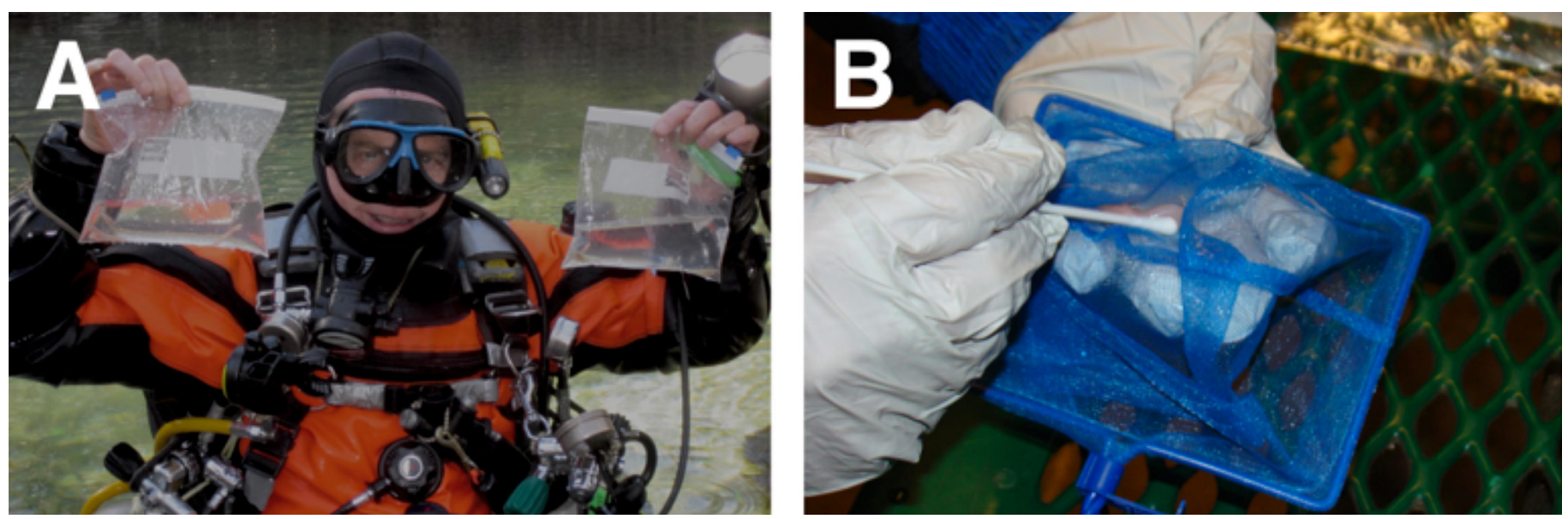

Fig. 5. Cave divers contributed to this study by collecting live salamanders (A). Each salamander was processed and all individuals subsequently were released at original sites of capture. The exceptions were individuals (12) that have been maintained in a captive colony, formerly at the Atlanta Botanical Garden and now at the San Antonio Zoo. Processing involved collecting a tissue sample for genetic analyses as well as collecting a non-invasive skin swab used to detect amphibian chytrid fungus (B). 
pette to clean $0.6 \mathrm{ml}$ microcentrifuge tubes. The recovered supernatant was then stored at $4^{\circ} \mathrm{C}$ until assayed using the quantitative real-time PCR protocol of Boyle et al. (2004) using $1 \mu \mathrm{l}$ of the extract as the DNA template.

\section{Results and Discussion}

Distribution, habitat and abundance.-Georgia Blind Salamanders are restricted to the subterranean waters of the Upper Floridan Aquifer in the Doughtery Plain of south-

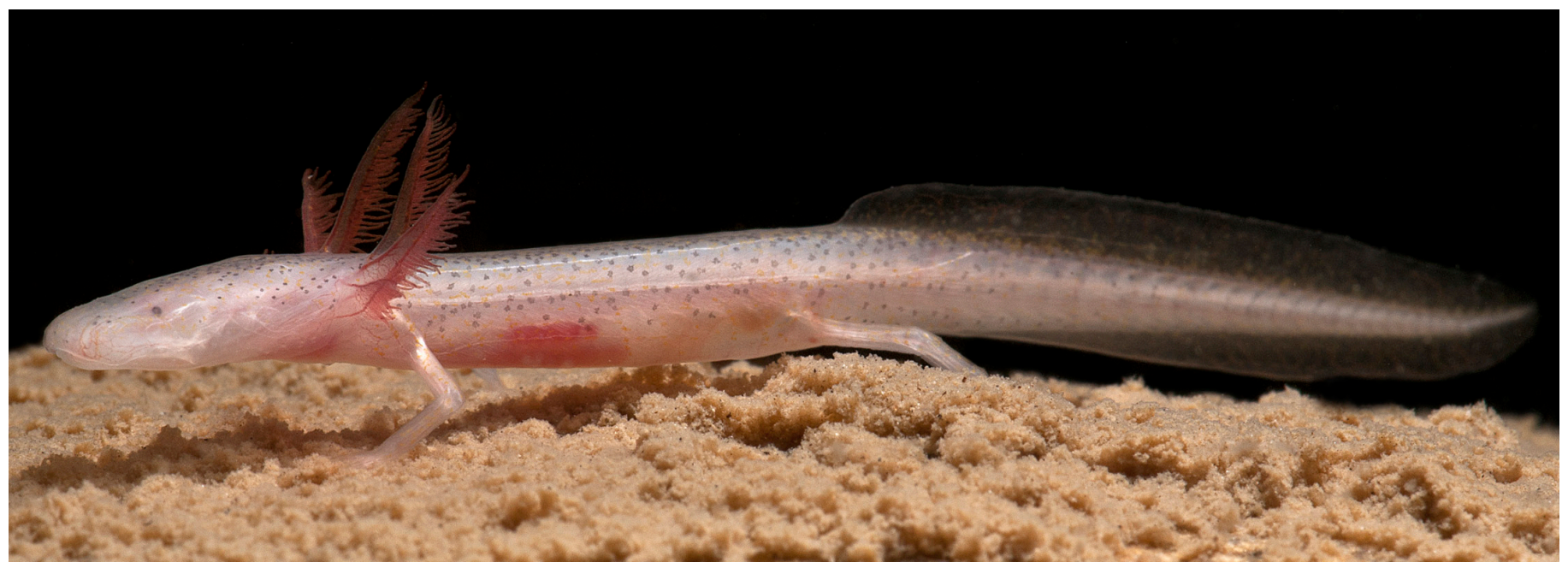

Fig. 6. Georgia Blind Salamanders frequently are observed foraging on the silt-covered bottoms of cave pools.

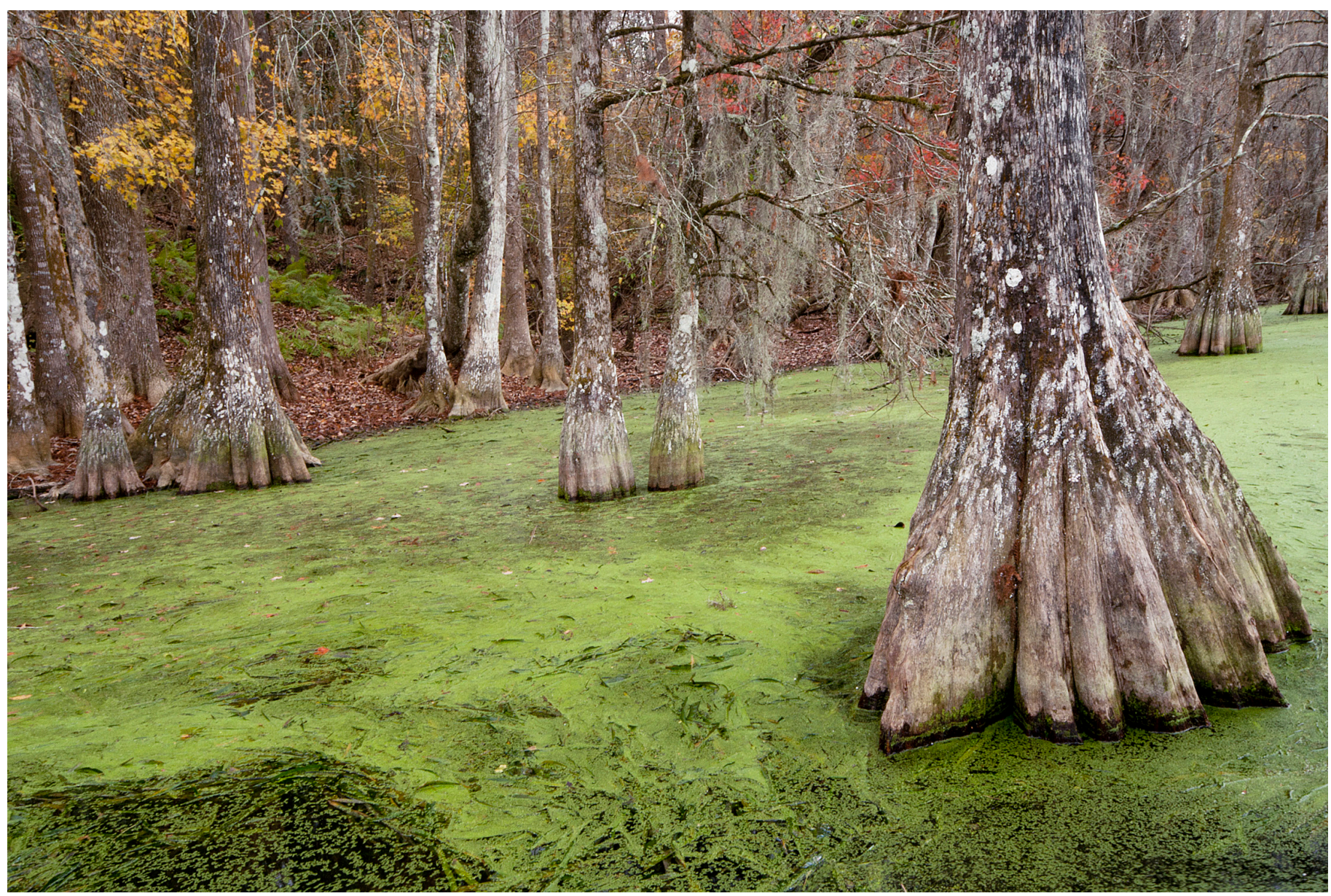

Fig. 7. The Floridan Aquifer feeds countless springs. The surface habitat where pools form, sometimes known as "blue holes," are often lined by cypress trees. This is Merritt's Mill Pond in Jackson County, Florida, where the density of salamanders was estimated at more than 10 individuals per square meter of silt-covered cave floor. 
western Georgia and adjacent northwestern Florida where the upper confining strata are thin or absent (Fig. 4). Included in its distribution are at least five United States Geological
Survey (USGS) HUC8 watersheds, including the Lower Flint, Middle Flint, Kinchafoonee-Muckalee, Chipola, and Lower Choctawhatchee watersheds. Eurycea wallacei is known from

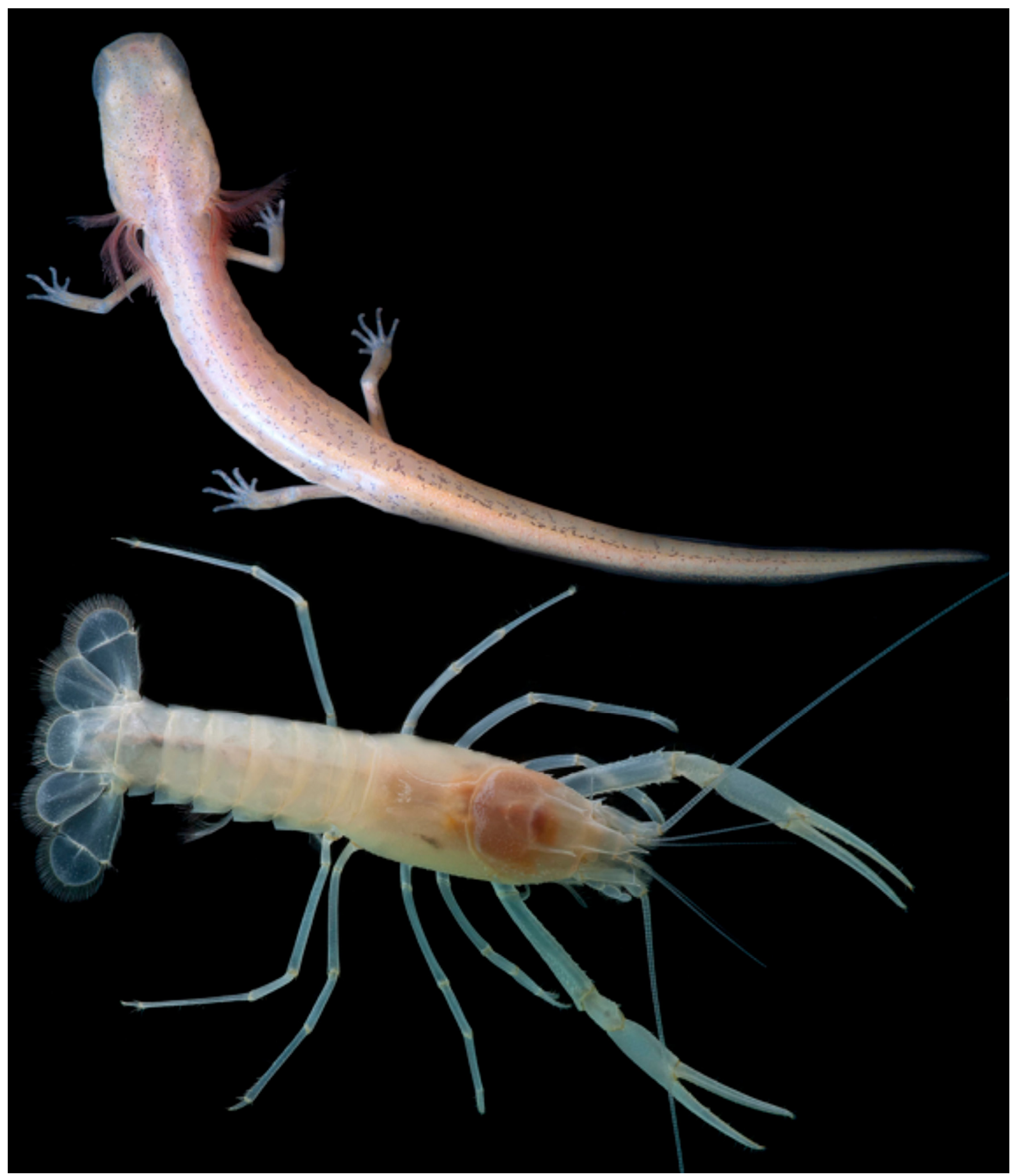

Fig. 8. The Georgia Blind Salamander (Eurycea wallacei) and the Dougherty Plain Cave Crayfish (Cambarus cryptodytes) are two of the top predators in the Floridan Aquifer. 
seven localities in Georgia, but Means (2005) reports that two of these sites have been destroyed by human activities, and since 1999, the species has been confirmed in Georgia from only one cave in Decatur County and two springs along the Flint River in Dougherty County. The species is known from more localities in Florida, including 23 localities in the Chipola River watershed of Jackson (22) and Calhoun (1) counties and five localities in the Lower Choctawhatchee River watershed of Washington County. Georgia Blind Salamanders likely occur at additional localities that exist between documented occurrences, such as undiscovered cave systems in Baker and Mitchell counties in Georgia. Moreover, the distribution of Georgia Blind Salamanders might include extreme southeastern Alabama as the Floridan Aquifer and Dougherty Plain extend into that state. However, limited access to this portion of the aquifer, i.e., springs that cave divers can enter, has presented challenges for sampling in this region.

Cave pools, streams and submerged passages inhabited by Georgia Blind Salamanders are characterized by limestone substrates often covered in a fine red clay or silt (Fig. 6; Means 1992, 2005, 2008). Water depths in these habitats range from a few $\mathrm{cm}$ to $>30 \mathrm{~m}$, although most submerged passages are 1-2 $\mathrm{m}$ deep. Although salamanders are found often resting on the bottom of pools, holes, or other areas with low flow, individuals are found also climbing on sidewalls, ledges, and even on the ceilings of submerged passages (Means 2008, Poucher 2011). In periods of low flow, cave divers often observe salamanders crawling over the sediment on the floors of flooded passageways and over limestone shelves. They also observe salamanders inhabiting cracks and crevices in the ceilings of these flooded passageways, floating downward in the water column after a diver passes by. During periods of high flow, cave divers observe fewer salamanders in the main passageways. Individuals that are encountered are concentrated in backwater eddies of flooded caverns where water flow is reduced. Water temperatures and $\mathrm{pH}$ range from $18-21^{\circ} \mathrm{C}$ and 7.6-8.2, respectively, and these subterranean waters are generally clear but become turbid after heavy rainfall.

Reliable estimates of population sizes are unknown for almost all populations because of the difficulty in accessing and sampling aquatic, subterranean habitats in this region by conventional means. Densities might be greater in areas of cave systems where bats roost over or near water, near sinkhole entrances, and other areas with energy inputs from the surface (Means 2008); however, no studies have yet substantiated this hypothesis. In cave systems with air-filled passages, juveniles are observed in greater densities in shallower habitats (Means 1992). Opsahl and Chanton (2006) suggested that methane-based microbial chemosynthetic pathways could serve as an energy source in remote aquifer locations; if so, these could provide food for larvae and adults of the focal species and help uncouple them from surface inputs. Some anecdotal evidence suggests that populations can be quite large. During a prolonged drought and associated low-flow conditions from 2009-2012, cave divers observed more Georgia Blind Salamanders than during any other period over the past 20 years. Divers reported observing $>100$ salamanders on single dives in at least three localities around the Marianna

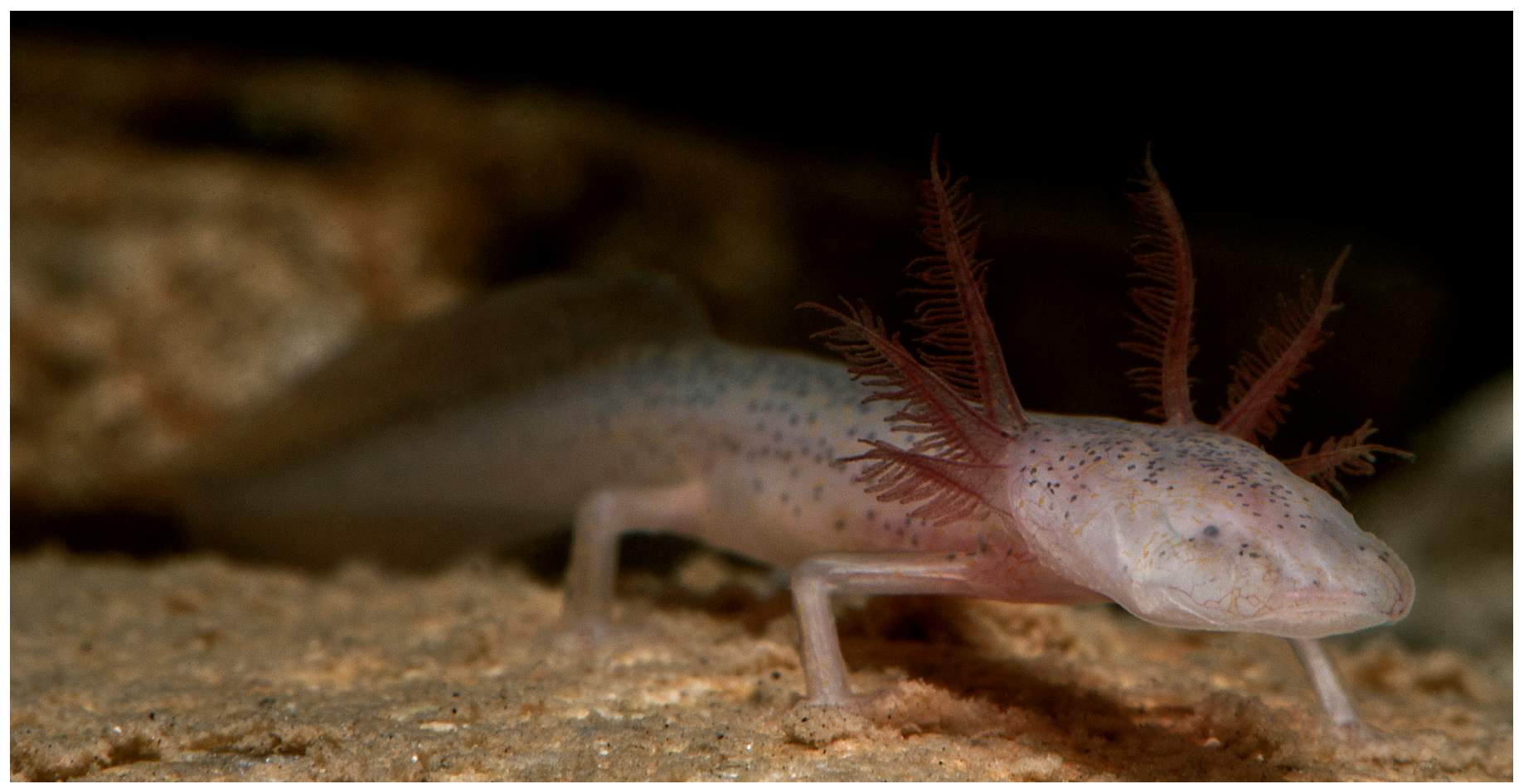

Fig. 9. The head of the Georgia Blind Salamander is broad, distinctly flattened, and shovel-shaped. 
Lowlands region in Jackson Co., Florida. In one area of a cave spring at Merritt's Mill Pond, Jackson Co., Florida (Fig. 7), the density of salamanders was estimated at more than 10 individuals per square meter of silt-covered cave floor.

Ecology and life history.-Little is known about ecology and life history of Georgia Blind Salamanders, particularly reproductive biology. Eggs and hatchlings have never been reported; however, gravid females have been observed in late May and in mid-November, suggesting asynchronous timing of reproduction (Means 1992, 2008). No studies have examined growth rate, age at sexual maturity, and life span. The majority of specimens captured by cave divers and examined in this study ranged $4-5 \mathrm{~cm}$ in total length. The diet consists primarily of small crustaceans, including amphipods (Crangonyx floridanus), copepods (Macrocyclops albidus) and unidentified ostracods (Lee 1969, Peck 1973). Lee (1969) found cave silt in the stomach of several salamanders and argued that they consume silt to digest entrained microorganisms. However, Peck (1973) believed that silt represented missed feeding attempts. We also observed silt in the digestive tracts (viewed through the transparent body wall) of a few individuals. Feeding in Georgia Blind Salamanders involves a snapping motion (Pylka and Warren 1958). However, we also have observed suction feeding of both living and prefrozen foods in captivity, as has been observed in other obligate stygobitic salamanders (Brandon 1971). "Transparent parasitic nematodes" have been found in the stomachs of some individuals collected in the Marianna Lowlands, and Lee (1969) observed "transparent parasitic nematodes" in the stomachs of individuals he collected in the Marianna area of Florida. Further, Lee (1969) reported numerous "nematodes protruding from the body wall" of another specimen that died in captivity. A tapeworm (Bothriocephalus sp.) was found in the small intestine of a Georgia Blind Salamander from Radium Springs in Georgia (McAllister et al. 2013).

The Dougherty Plain Cave Crayfish (Cambarus cryptodytes; Fig. 8) is a community associate in subterranean waters inhabited by Georgia Blind Salamanders and has been hypothesized to be a predator of the salamander (Means

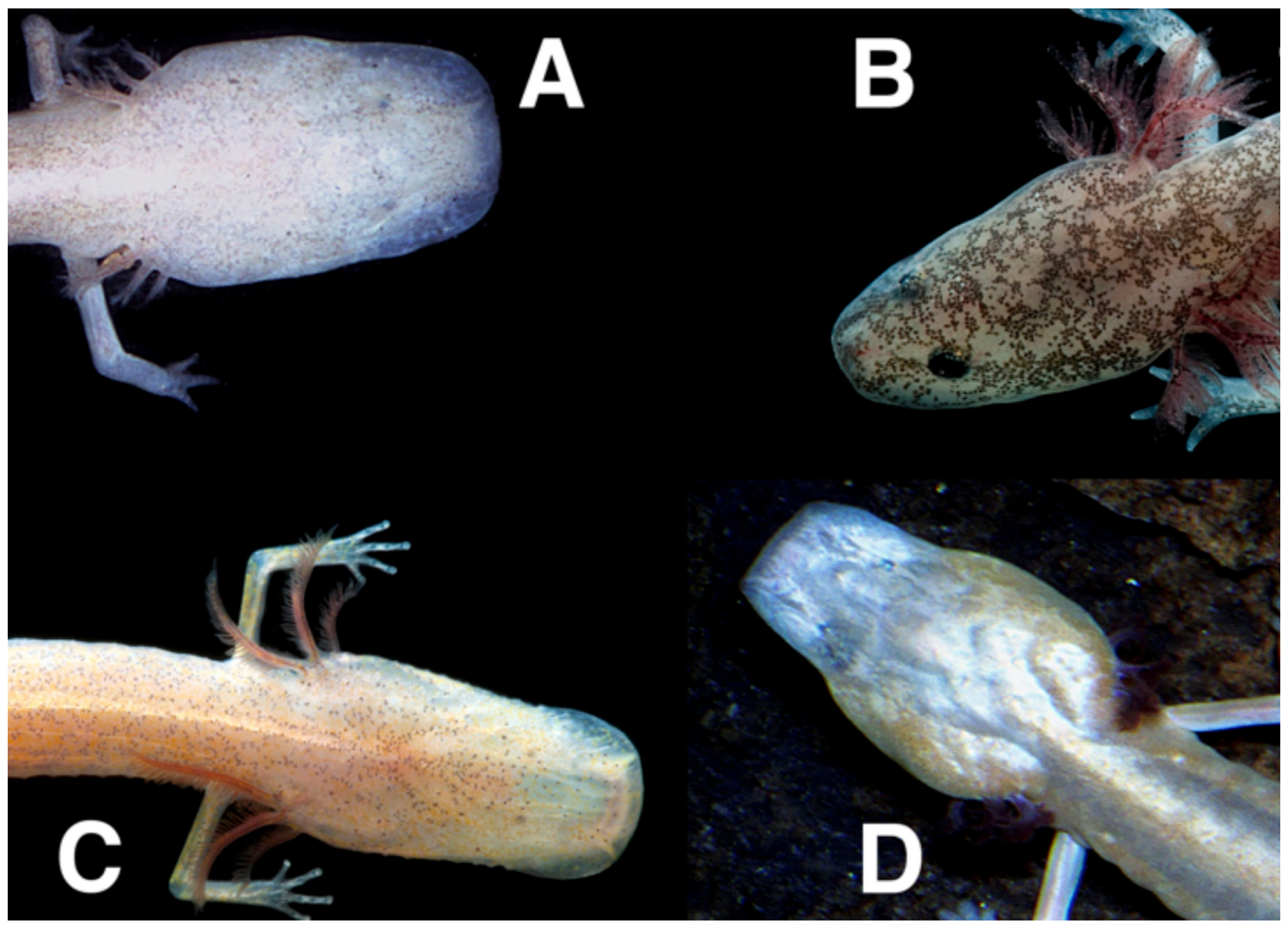

Fig. 10. Head shape of four adult stygobitic salamanders in the genus Eurycea: (A) Eurycea pterophila, Guadalupe State Park, Comal Co., Texas; (B) E. latitans, Cascade Caverns, Kendall Co., Texas; (C) E. wallacei, Black Hole Spring, Jackson Co., Florida; (D) E. rathbuni, Hayes Co., Texas. 


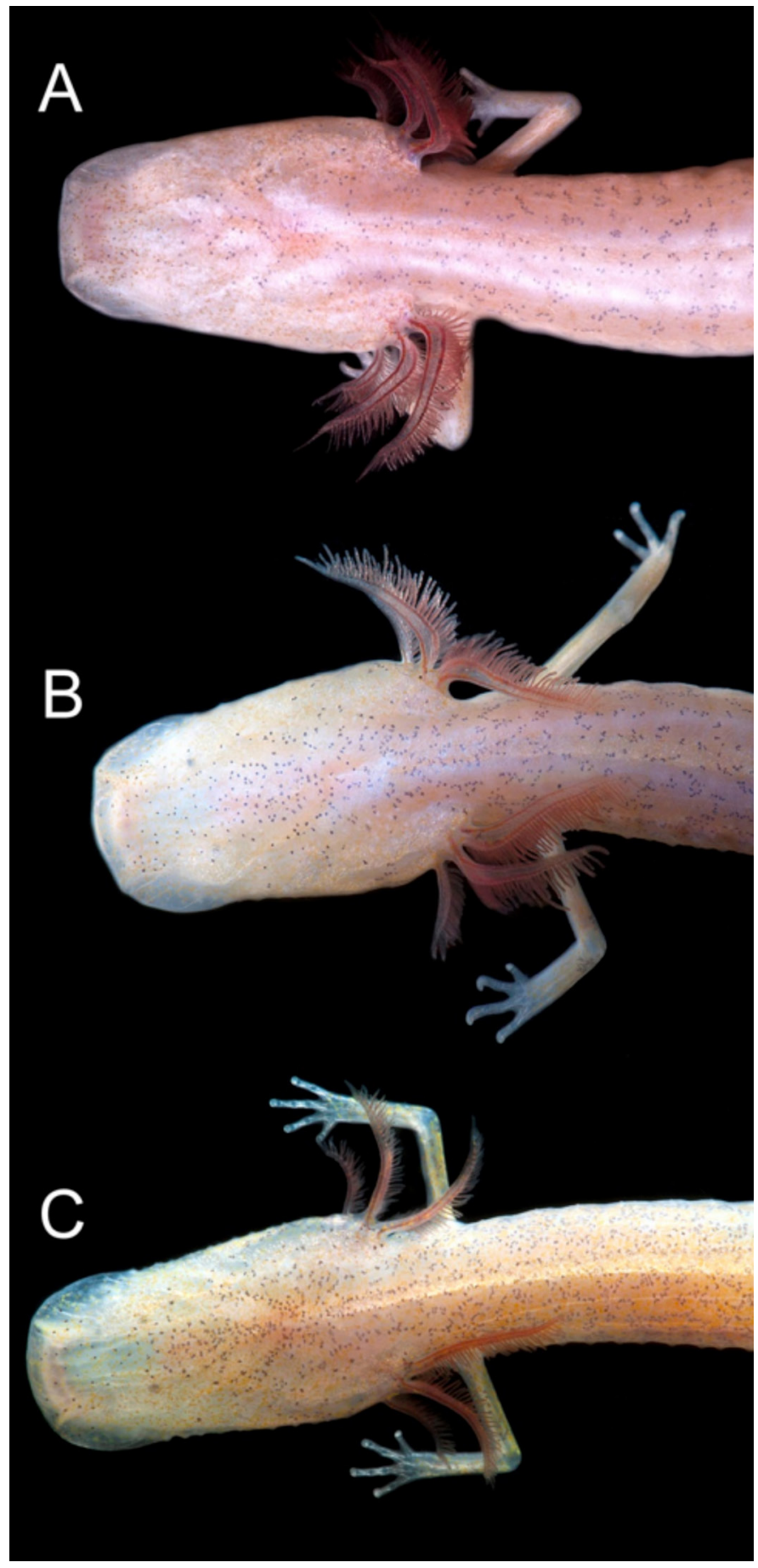

Fig. 11. Head shape in the Georgia Blind Salamander (Eurycea wallacei) is variable. Some individuals have a more triangular head $(\mathrm{A})$, whereas others have a more elongate and narrow head shape $(\mathrm{C})$ and still others are intermediate in head shape (B).

1992). During a survey in Jackson Blue Spring, Jackson Co., Florida, divers observed a Dougherty Plain Cave Crayfish grasping a live Georgia Blind Salamander in its cheliped, confirming Mean's (1992) hypothesis. Other potential predators include American Eels (Anguilla rostrata), Brown Bullheads
(Ameirus nebulosus), and Redeye Chubs (Notropis harperi; Means 1992, 2005, 2008).

Georgia Blind Salamanders are observed often in a characteristic body posture wherein both the body and head are elevated from the substrate with outstretched limbs (Fig. 2A; Carr 1939). This body orientation may enhance the efficiency of the lateral-line system (Poulson 1964, Brandon 1971, Peck 1973). The lateral-line system also is well-developed on the head and snout of E. wallacei. The head shape has been described as broad but not particularly flattened (Conant and Collins 1998, Petranka 1998). However, we disagree with this statement based on examination of more than 50 live individuals in the Marianna Lowlands of Jackson Co., Florida, which have heads that are as flattened (Fig. 9), or even more so, than other stygobitic Eurycea, such as the Texas Blind Salamanders (E. rathbuni), the Blanco River Spring Salamander (E. pterophila), and the Cascade Caverns Salamander (E. latitans) (Fig. 10). Variation in head shape appears to be relatively common in populations of Georgia Blind Salamanders (Fig. 11). Adults can have a head shape that is more triangular with less "flaring" of the rostral edges toward the anterior portion of the skull (Fig. 11A), a more elongate head with considerable "flaring" of the rostral edges (Fig 11C) or a condition intermediate to the two (Fig. 11B). In all cases, the skull is longer than it is wide and is dorsoventrally flattened, as is seen in other obligate groundwater salamanders, such as E. rathbuni and E. waterlooensis.

\section{Threats to Georgia Blind Salamanders and associated} groundwater fauna.- Groundwater organisms are facing a plethora of threats and we may lose substantial diversity of these organisms in some regions before we have a chance to understand their biology and ecology. Threats include the direct destruction of suitable habitat. For example, of seven populations of E. wallacei monitored in Georgia from 1970 to 1992, five were reported as "stable," but two were destroyed by human activities (Means 2005). Other threats are more subtle. Human activities on the surface and within recharge zones of aquifers can degrade groundwater quality, threatening future human use of the resource as well as the subterranean biological communities living there (Crunkilton 1982, 1984; Tercafs 1992; Simon and Buikema 1997; Wood et al. 2002; Graening and Brown 2003; Graening et al. 2012).

Groundwater contamination, such as agricultural pollution and industrial runoff, are of particular concern and several studies have documented the risks it poses for groundwater quality (Crunkilton 1982, 1984; Gunn et al. 2000; Culver et al. 2000; Wood et al. 2002; Graening et al. 2012). The risk of groundwater contamination in the United States is greatest in agricultural areas where, ironically, an estimated $95 \%$ of local residents rely directly on this resource for their freshwater needs (USGS 2005). Groundwater communities include 
organisms, such as amphibians and invertebrates, which are sensitive to environmental perturbations, particularly fertilizers, pesticides, and other chemicals (Cole and Casida 1983; Crunkilton 1982, 1984; Hecnar 1995; Sparling et al. 2001; de Wijer et al. 2004; Relyea 2005abc). Because an aquifer is the only available habitat for groundwater fauna, any change in water quality, especially contamination of it, can poison an environment; stygobitic organisms cannot seek refuge elsewhere. Consequently, groundwater contamination is a serious threat to Georgia Blind Salamanders and includes contamination from septic tank effluent, fertilizers, pesticides, hazardous wastes, surface runoff from impervious surfaces, waste from cattle ranches and dairy farms, and siltation and erosion caused by divers and recreationalists in caves, springs, sinkholes, and in the vicinity of blind salamander sites (Brandt and Jackson 2003; FFWCC 2011). The Floridan Aquifer has been designated as an at-risk aquifer for fertilizer contamination by the United States Geological Survey (Nolan et al. 1998); however, no regular monitoring protocols have been initiated to monitor changes in the populations of endemic stygobitic fauna within the aquifer.

Georgia Blind Salamanders also are threatened by manipulation of the local hydrology of the cave systems that they inhabit. Anthropogenic or natural changes in groundwater levels can alter hydrology and water chemistry of critical habitat (Means 1992). Impoundments raise local water tables and could negatively impact populations of the salamander by changing hydrological patterns, gas concentrations in groundwater, available nutrients, and access to subterranean habitats by potential predators. However, Georgia Blind Salamanders, including small, presumably young individuals, are regularly seen in springs that have been flooded since 1860, forming the 270-acre Merritt's Mill Pond in Jackson Co., Florida (Dodson 2013). Conversely, excessive groundwater extraction associated with irrigation, particularly with center pivot irrigation systems, and excessive water demand by growing human populations and sprawl can lower local water tables, potentially reducing habitat available to the species.

Guano from cave-roosting bat colonies is an important source of organic input in many cave systems that are otherwise energy-limited (Culver and Pipan 2009), and this nutrient source has been tied to the dietary intake of subterranean salamanders (Fenolio 2003, Fenolio and Trauth 2005, Fenolio et al. 2006). Bat declines or the loss of local bat populations could threaten Georgia Blind Salamanders. For example, if juveniles are more reliant on higher energy-input microhabitats, such as cave pools below bat roosts, younger individuals may be particularly vulnerable to decreases in bat

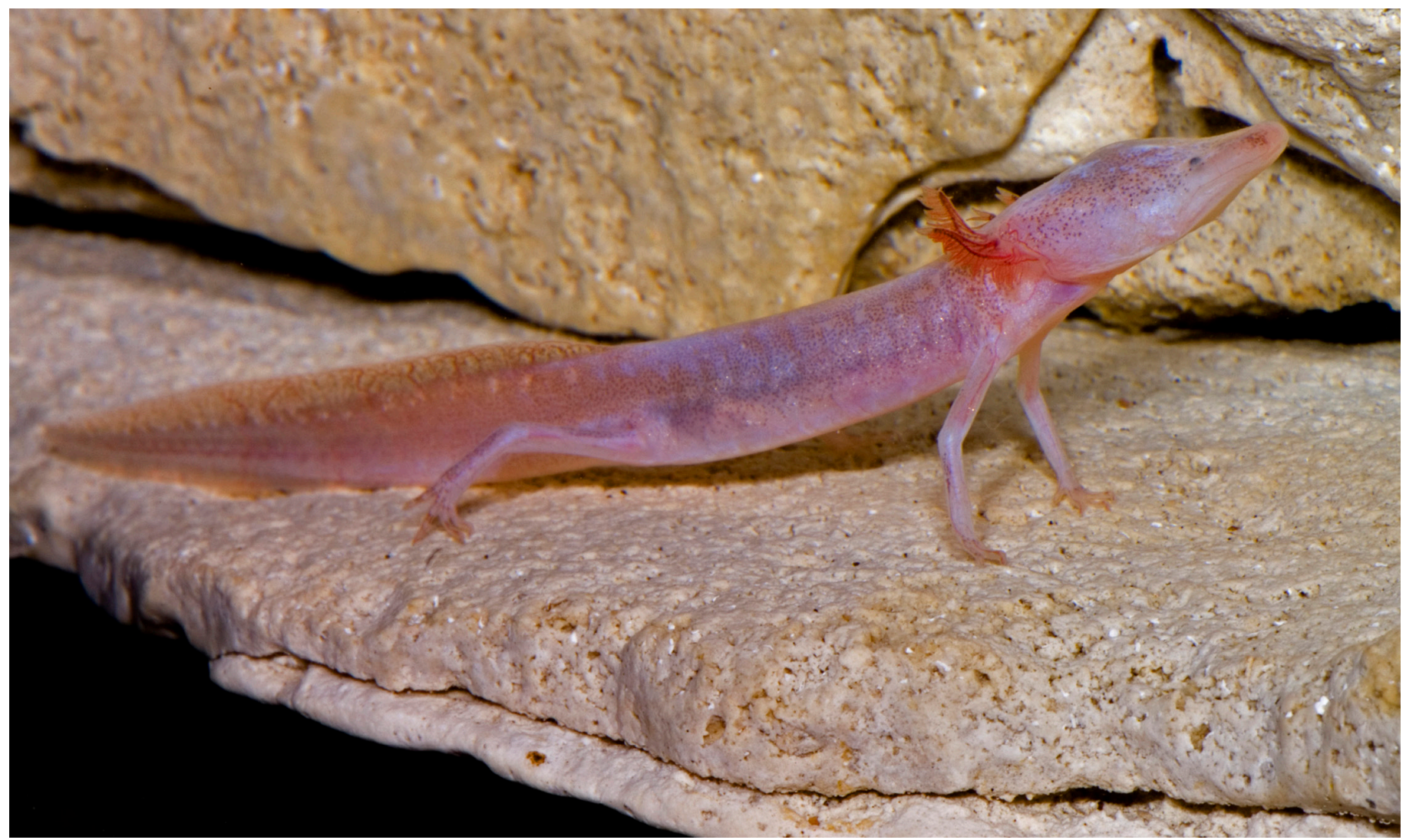

Fig. 12. This is an aquifer-inhabiting salamander in the genus Eurycea from south Texas. Note the coloration (or lack thereof), the shovel-shaped head, and the feathery external gills. All of these characters are shared with the Georgia Blind Salamander (Eurycea wallace $i$ ). 
populations. Studies are needed to determine whether the abundance of younger Georgia Blind Salamanders in shallow cave pools is associated with cave-roosting bats.

Like other cave vertebrates, this species could be exploited for the pet trade. Likewise, over-collection for scientific studies is a concern. At least 147 accessions of Georgia Blind Salamanders exist in university and museum herpetological collections, based on a query of 56 collections on HerpNet. Most of these accessions ( $>70)$ are from one locality northwest of Marianna in Jackson Co., Florida; other localities have received limited scientific collection pressure. Collecting Georgia Blind Salamanders without permits is illegal in Florida and Georgia. The extent of illegal collection is impossible to quantify, but likely is small because of the difficulty in accessing the subterranean habitat. Over-collection for amateur or scientific purposes could in principle reduce or possibly extirpate local populations; however, no evidence suggests that over-collection poses an immediate and significant threat to the species. Habitat disturbance caused by recreational cavers and cave divers is unlikely to pose a significant threat to Georgia Blind Salamanders; no evidence points to any detrimental impacts to salamander populations caused by recreational activities. The primary source of information on the distribution and abundance of Georgia Blind Salamanders comes from recreational cavers and cave divers.

Several population declines and extinctions of amphibians in the last 25 years have been linked to the emergent infectious disease, amphibian chytrid fungus, Batrachochytrium dendrobatidis or Bd (Longcore et al. 1999, Berger et al. 1998, Daszak et al. 2003, Lips et al. 2003, Muthsa et al. 2003, Mendelson et al. 2004, Rachowicz et al. 2006, Schloegel et al. 2006). Although $B d$ has been confirmed for several species in the United States, its presence has not been well documented for any of the nine cave-obligate salamanders in the U.S. However, five species of related spring-dwelling salamanders have tested positive for $B d$ in Central Texas, including the Texas Salamander (E. neotenes), the Blanco River Springs Salamander (E. pterophila), the San Marcos Salamander (E. nana), the Barton Springs Salamander (E. sosorum) and the Jollyville Plateau Salamander (E. tonkawae) (O'Donnell et al. 2006, Gaertner et al. 2009). We tested 41 Georgia Blind Salamanders from seven localities in three counties of Georgia and Florida (Table 1). No salamanders tested positive for $B d$; however, the fungus has been detected in populations of surface-dwelling amphibians within the range of the species.

Conservation status. - The Georgia Blind Salamander is listed as "Vulnerable" by the IUCN (Hammerson 2004) and "Imperiled" (G2) by NatureServe (Natureserve 2013). Its "Vulnerable" listing by the IUCN is because of the limited extent of occurrence and area of occupancy, a severely fragmented distribution, and the likelihood of continuing decline in the quality of its habitat (Hammerson 2004). The "Imperiled" NatureServe status is based on a limited geographic distribution, low number of occurrences, very narrow environmental specificity, a decline in area of occupancy and population size in the past 40 years, and threats from agricultural runoff, water level fluctuations, and overcollecting (NatureServe 2013). The Florida Fish and Wildlife Conservation Commission (2011) predicted a decline in groundwater quality and quantity across the range of Georgia Blind Salamanders. Consequently, they also predicted a decline in the species and made an official recommendation of upgrading the status of the salamander to "Threatened" in Florida. Georgia Blind Salamanders also are listed as "Threatened" in Georgia because the species is known from just three localities and the potential threats affecting these populations. Our evaluation of the conservation status of Georgia Blind Salamanders is in agreement with these past assessments, although the distribution is slightly larger than previously reported.

Conservation actions. - Reports indicate that as many as a third of all known amphibian species, many of which inhabit areas far from obvious human disturbances, are in decline (Stuart et al. 2004). We suggest that increased understanding of species listed as "Data Deficient" by the IUCN may lead to an estimate of $40-50 \%$ of all amphibians in decline. Species with unusual life histories, habitats, reproductive modes, novel biochemical qualities, divergent behaviors, or unique gene pools must be included on the list of species for which intensive conservation efforts are implemented (Fig. 12). The Georgia Blind Salamander, with its neotenic life history and extremely specialized habitat, is one of these species. As we work to understand the causes of declines, essential conservation actions for saving species must be undertaken immediately to help slow the loss of amphibian biodiversity (Mendelson et al. 2006).

Perhaps the most important conservation action for Georgia Blind Salamanders is the protection of the recharge zones and critical karst features, such as sinkholes and cave systems inhabited by the species. This includes the regulation of land use and natural resource harvest practices that may threaten Georgia Blind Salamanders. These include minimizing agricultural pollution and limiting the harvest of groundwater for irrigation. Of the 35 documented populations, only three are afforded any protection: two populations occur in Marianna Caverns State Park in Florida, and Radium Springs is protected in Georgia. All other localities are on private lands. Efforts should be made to establish conservation easements on private lands or even acquire these properties by conservation agencies or organizations within the recharge zones of cave systems containing Georgia Blind Salamanders (Jensen 2007). 
The Floridan Aquifer where Georgia Blind Salamanders live is an "at-risk" aquifer owing to contamination from agricultural activities within the recharge zone of the aquifer (Nolan et al. 1998). Strict regulations controlling the herbicides and pesticides used in agricultural practices, their containment and retainment on the surface, and runoff systems that have a capacity to filter contaminants from the runoff are required (e.g., Higgins et al. 1993, Moore et al. 2000, Lin et al. 2002, Jordan et al. 2003, Krutz et al. 2005). Further, strict regulations limiting the amount of water extracted for irrigation as well as more water-efficient agricultural methods are in dire need in this region. The irony is that a significant portion of local residents rely directly on groundwater for their personal freshwater needs. The system that is currently in place is unsustainable in the long-term and will likely harm humans as much as it harms groundwater fauna (Bacchus 2000, Bacchus et al. 2003).

Another recommendation is to resurvey and monitor known localities while also searching for new cave systems that may contain Georgia Blind Salamanders. Questions remain as to whether known populations are severely isolated or more connected than previously thought. Surveys are needed to determine if distributional gaps in Georgia are real or if populations occur between northern and southern populations in the state. The establishment of long-term monitoring programs also is needed to provide data on population sizes and water quality over time.

The Amphibian Conservation Action Plan (a product of the Amphibian Conservation Summit 2005; Gascon et al. 2005) listed the following as important steps to help stem amphibian declines: (1) The implementation of collaborations that span international boarders so as to best facilitate complex conservation activities, (2) a developed understanding of the current extent of declines across the range of target species, (3) a well developed plan for captive propagation of critically endangered taxa, and (4) a well-developed public education program to facilitate interest in and support for amphibian decline countermeasures. We are working to address step 3 by establishing captive management and breeding protocols for Georgia Blind Salamanders so that assurance colonies could be established in short order should the species decline as predicted here and by other authors (e.g., Means 2005). We have recently installed a small laboratory (formerly in a facility at the Atlanta Botanical Garden and now in a facility at the San Antonio Zoo) to develop captive care and reproduction protocols for the Georgia Blind Salamander after Belcher's (1988) design for the Texas Blind Salamander (E. rathbuni). This colony is intended to serve as a model for assurance colonies for this species. Ten-gallon aquaria on enamel-coated racks are plumbed into a central filtration unit. This filtration unit is filled with limestone from one of the localities where salamanders have been collected. The approach includes using local limestone so that any trace minerals that may be present also are present in the water of the system. A chiller maintains the water temperature at $68^{\circ} \mathrm{F}$, the groundwater temperature in the aquifer where Georgia Blind Salamanders are found. Capacity for 24 groups of salamanders is present, although much smaller groups have been collected to start the project. Live individuals $(\mathrm{n}=12)$ have been collected from five populations in Florida and one population in Georgia. The animals are feeding and have exhibited several behaviors that might be associated with reproduction.

Conclusions. - Considerable strides have been made in the last ten years, improving our understanding of the biology and ecology of groundwater-inhabiting salamanders; however, much work remains. Conservation threats have been identified for a number of groundwater-inhabiting salamanders and more studies are being published regarding activities that might help slow the loss of biodiversity in this group. While we found no evidence that Georgia Blind Salamanders have been infected by amphibian chytrid fungus, clear threats remain to the long-term persistence of this species. Key threats include: (1) An "at-risk" ranking by the United States Geological Survey (Nolan et al. 1998) of the Floridan Aquifer for contamination, the only known habitat for this species; (2) overharvesting of groundwater, especially with intensive center pivot irrigation used across the region; (3) the presence of an emergent infectious amphibian disease in surface amphibians within the region (i.e., amphibian chytrid fungus); and (4) the lack of understanding of the basic biology and ecology of the species, which is needed to develop captive management protocols and captive reproduction methods. We recommend the following conservation activities to help prevent the loss of this unique aquifer inhabiting amphibian: (1) Better regulations and improved methods for retaining pesticide and fertilizer contaminants on the surface or the replacement of current crops with crops that require fewer chemicals, (2) regulatory review of agricultural crops grown in the region and the establishment of systems and crops that do not require center pivot irrigation, (3) regular monitoring for disease across the range of the species, and (4) establishment of multiple assurance colonies such that captive specimens genetically represent at least half of the known populations.

\section{Acknowledgements}

We thank Tree Walkers International (Grant no. 001) and Lee Moran for financial support. Jim Clark, Kelly Jessop, Mike Stine, and Bonnie Stine provided cave-diving support. Paul Moler and K. Denise Kendall assisted in the field. The Atlanta Botanical Garden provided logistical support. Mark Mandica, Leslie Phillips, and the Atlanta Botanical Garden assisted with live animal care. Live specimens were collected 
from Florida under FFWCC permit No. LSSC-09-0288 and from Georgia under GADNR permit No. 29-WBH-09-190.

\section{Literature Cited}

Bacchus, S.T. 2000. Uncalculated impacts of unsustainable aquifer yield including evidence of subsurface interbasin flow. Journal of the American Water Resources Association 36:457-481.

Bacchus, S.T., D.D. Archibald, G.A. Brook, K.O. Britton, B.L. Haines, S.L. Rathbun, and M. Madden. 2003. Near-infrared spectroscopy of a hydroecological indicator: New tool for determining sustainable yield for Floridan Aquifer system. Hydrological Processes 17:1785-1809.

Belcher, D.L. 1988. Courtship behavior and spermatophore deposition by the subterranean salamander, Typhlomolge rathbuni (Caudata, Plethodontidae). Southwestern Naturalist 33:124-126.

Berger, L., R. Speare, P. Daszak, D.E. Green, A.A. Cunningham, C.L. Goggin, R. Slocombe, M.A. Ragan, A.D. Hyatt, K.R. McDonald, H.B. Hines, K.R. Lips, G. Marantelli, and H. Parkes. 1998. Chytridiomycosis causes amphibian mortality associated with population declines in the rain forests of Australia and Central America. Proceedings of the National Academy of Sciences 95:9031-9036.

Brandon, R.A. 1967. Haideotriton and H. wallacei. Catalogue of American Amphibians and Reptiles (39):1-2.

Brandon, R.A. 1971. North American troglobitic salamanders: Some aspects of modification in cave habitats, with special reference to Gyrinophilus palleucus. National Speleological Society Bulletin 33:1-21.

Boyle, D.G., D.B. Boyle, V. Olsen, J.A.T. Morgan, and A.D. Hyatt. 2004. Rapid quantitative detection of chytridiomycosis (Batrachochytrium dendrobatidis) in amphibian samples using real-time PCR assay. Diseases of Aquatic Organisms 60:141-148.

Brandt, K. and D.R. Jackson. 2003. Protecting the habitat of the Florida Cave Salamander in Jackson County's spring caves. Final Report to Florida Department of Environmental Protection, Tallahassee, Florida.

Carr, A.F. 1939. Haideotriton wallacei. A new subterranean salamander from Georgia. Occasional Papers of the Boston Society of Natural History 8:333-336.

Cole, L.M. and J.E. Casida. 1983. Pyrethroid toxicology in the frog. Pesticide Biochemistry and Physiology 20:217-224.

Conant, R. and J.T. Collins. 1998. A Field Guide to Reptiles and Amphibians: Eastern and Central North America. Third Edition, expanded. Houghton Mifflin Company, New York.

Crunkilton, R. 1982. Bitter harvest. Missouri Conservationist November:4-7.

Crunkilton, R. 1984. Subterranean contamination of Meramac Spring by ammonia nitrate and urea fertilizer and its implication on rare cave biota. Proceedings of the 1984 National Cave Management Symposium. Journal of the Missouri Speleological Society 25:151-158.

Culver, D.C., L.L. Master, M.C. Christman, and H.H. Hobbs III. 2000. Obligate cave fauna of the 48 contiguous United States. Conservation Biology 14:386401.

Culver, D.C. and T. Pipan. 2009. The Biology of Caves and Other Subterranean Habitats. $2^{\text {nd }}$ edition. Oxford University Press, Oxford, U.K.

de Wijer, P., P.J. Watt, and R.S. Oldham. 2004. Amphibian decline and aquatic pollution: Effects of nitrogenous fertilizer on survival and development of larvae of the frog Rana temporaria. Applied Herpetology 1:3-12.

Daszak, P., A.A. Cunningham, and A.D. Hyatt. 2003. Infectious disease and amphibian population declines. Diversity and Distributions 9:141-150.

Dodson, J. 2013. Final Report: Nutrient TMDL for Jackson Blue Spring and Merrits Mill Pond (WBIDs 180Z and 180A). Florida Department of Environmental Protection, Division of Environmental Assessment and Restoration, Bureau of Watershed Restoration, Northwest DistrictApalachicola-Chipola Basin, Tallahassee.

Dundee, H.A. 1962. Response of the neotenic salamander Haideotriton wallacei to a metamorphic agent. Science 135:1060-1061.

Fenolio, D. 2003. Ecology and population dynamics of the Grotto Salamander, Typhlotriton spelaeus. Unpublished M.S. Thesis, University of Oklahoma, Norman.

Fenolio, D. and S. Trauth. 2005. Eurycea (Typhlotriton) spelaea, pp. 863-866. In: M. Lannoo (ed.), Amphibian Declines in North America. University of California Press, Berkeley.
Fenolio, D.B., G.O. Graening, B.A. Collier, and J.F. Stout. 2006. Coprophagy in a cave-adapted salamander; the importance of bat guano examined through stable isotope and nutritional analyses. Proceedings of the Royal Society B 273:439-443.

Florida Fish and Wildlife Conservation Commission. 2011. Biological status review for the Georgia Blind Salamander, Eurycea wallacei. Florida Fish and Wildlife Conservation Commission, Tallahassee.

Frost, D.R., T. Grant, J. Faivovich, R.H. Bain, A. Haas, C.F.B. Haddad, R.O. De Sa, A. Channing, M. Wilkinson, S.C. Donnellan, C.J. Raxworthy, J.A. Campbell, B.L. Blotto, P. Moler, R.C. Drewes, R.A. Nussbaum, J.D. Lynch, D.M. Green, and W.C. Wheeler. 2006. The amphibian tree of life. Bulletin of the American Museum of Natural History (297):1-370.

Gaertner, J.M., R.J. Forstner, L. O'Donnell, and D. Hahn. 2009. Detection of Batrachochytrium dendrobatidis in endemic salamander species from central Texas. EcoHealth 6:20-26.

Gascon, C., J.P. Collins, R.D. Moore, D.R. Church, J.E. McKay, and J.R. Mendelson III (eds.). 2005. Amphibian Conservation Action Plan. Proceedings IUCNISSC Amphibian Conservation Summit. The World Conservation Union (IUCN), Gland, Switzerland.

Goricki, S., M.L. Niemiller, and D.B. Fenolio. 2012. Salamanders, pp. 665-676 In: W.H. White and D.C. Culver (eds.), Encyclopedia of Caves. $2^{\text {nd }}$ edition. Academic Press, Waltham, Massachusetts.

Graening, G.O. and A.V. Brown. 2003. Ecosystem dynamics and pollution effects in an Ozark cave stream. Journal of the American Water Resources Association 39:1497-1507.

Graening, G.O., D.B. Fenolio, and M.E. Slay, 2012. The Cave Life of Oklahoma and Arkansas. University of Oklahoma Press, Norman.

Gunn, J. 1991. Water tracing experiments in the Castleton karst, 1950-1990. Cave Science 18:43-46.

Hammerson, G. 2004. Eurycea wallacei. In: IUCN 2012. IUCN Red List of Threatened Species. Version 2012.2. (www.iucnredlist.org).

Hecnar, J.S. 1995. Acute and chronic toxicity of ammonium nitrate fertilizer to amphibians from southern Ontario. Environmental Toxicology and Chemistry 14:2131-2137.

Higgins, M.J., C.A. Rock, R. Bouchard, and B. Wengrezynek. 1993. Controlling agricultural runoff by use of constructed wetlands, pp. 359-368. In: G.A. Moshiri (ed.), Constructed Wetlands for Water Quality Improvement. Lewis Publishers and CRC Press, Boca Raton, Florida.

Jensen, J.B., C.D. Camp, W. Gibbons, and M.J. Elliott. 2008. Amphibians and Reptiles of Georgia. University of Georgia Press, Athens.

Jordan, T.E., D.F. Whigham, K.H. Hofmockel, and M.A. Pittek. 2003. Nutrient and sediment removal by a restored wetland receiving agricultural runoff. Journal of Environmental Quality 32:1534-1547.

Krutz, L.J., S.A. Senseman, R.M. Zablotowicz, and M.A. Matocha. 2005. Reducing herbicide runoff from agricultural fields with vegetative filter strips: A review. Weed Science 53:353-367.

Lee, D.S. 1969. A food study of the salamander Haideotriton wallacei Carr. Herpetologica 25:175-177.

Lin, C.Y., W.C. Chou, and W.T. Lin. 2002. Modeling the width and placement of riparian vegetative buffer strips: A case study on the Chi-Jia-Wang Stream, Taiwan. Environmental Management 66:269-280.

Lips, K., D.E. Green, and R. Papendick. 2003. Chytridiomycosis in wild frogs from southern Costa Rica. Journal of Herpetology 37:215-218.

Longcore J.E., A.P. Pessier, and D.K. Nichols 1999. Batrachochytrium dendrobatidis gen. et sp. nov., a chytrid pathogenic to amphibians. Mycologia 91:219-227.

McAllister, C.T., C.R. Bursey, D.B. Fenolio, and M.L. Niemiller. 2013. Bothriocephalus sp. (Cestoidea: Bothriocephalidea: Bothriocephalidae) from the Georgia Blind Salamander, Eurycea wallacei (Caudata: Plethodontidae), in Georgia, USA: First definitive report of a parasite from this host. Comparative Parasitology 80:308-311.

Means, D.B. 1977. Aspects of the significance to terrestrial vertebrates of the Apalachicola River drainage basin, Florida, pp. 37-67. In: R.J. Livingston and E.A. Joyce (eds.), Proceedings of the Conference on the Apalachicola Drainage System. Florida Marine Research Publication Number 26, Tallahassee, Florida.

Means, D.B. 1992. Georgia Blind Salamander, Haideotriton wallacei Carr, pp. 49-53. In: P. Moler (ed.), Rare and Endangered Biota of Florida. Volume III. Amphibians and Reptiles. University Press of Florida, Gainesville. 
Means, D.B. 2005. Haideotriton wallacei Carr, 1939, pp. 779-780. In: M.J. Lanoo (ed.), Amphibian Declines: The Conservation Status of United States Species. University of California Press, Berkeley and Los Angeles.

Mendelson, J.R. III, K.R. Lips, R.W. Gagliardo, G.B. Rabb, J.P. Collins, J.E. Diffendorfer, P. Daszak, R. Ibáñez, K.C. Zippel, D.P. Lawson, K.M. Wright, S.N. Stuart, C. Gascon, H.R. da Silva, P.A. Burrowes, R.L. Joglar, E. La Marca, S. Lötters, L.H. du Preez, C. Weldon, A. Hyatt, J.V. RodriguezMahecha, S. Hunt, H. Robertson, B. Lock, C.J. Raxworthy, D.R. Frost, R.C. Lacy, R.A. Alford, J.A. Campbell, G. Parra-Olea, F. Bolaños, J.J. Calvo Domingo, T. Halliday, J.B. Murphy, M.H. Wake, L.A. Coloma, S.L. Kuzmin, M.S. Price, K.M. Howell, M. Lau, R. Pethiyagoda, M. Boone, M.J. Lannoo, A.R. Blaustein, A. Dobson, R.A. Griffiths, M.L. Crump, D.B. Wake, and E.D. Brodie, Jr. 2006. Confronting amphibian declines and extinctions. Science 313:48.

Moore, M.T., J.H. Rodgers, Jr., C.M. Cooper, and S. Smith, Jr. 2000. Constructed wetlands for mitigation of atrazine-associated agricultural runoff. Environmental Pollution 110:393-399.

Morris, T.L. 2006. A biological inventory of aquifer caves in Florida with special emphasis on troglobitic crustaceans and salamanders. Final Report to Florida Department of Environmental Regulation, Research Grant Agreement S0057, Tallahassee, Florida.

Muthsa E., P.S. Corn, A.P. Pessierc, and D.E. Greend. 2003. Evidence for diseaserelated amphibian decline in Colorado. Biological Conservation 110:357-365.

NatureServe. 2013. NatureServe Explorer: An Online Encyclopedia of Life [web application]. Version 7.1. NatureServe, Arlington, Virginia (www.natureserve.org/explorer).

Nolan B.T., B.C. Ruddy, K.J. Hitt, and D.R. Helsel. 1998. A national look at nitrate contamination of ground water. Water Conditioning and Purification 39:76-79.

O'Donnell, L., P. Turner, M.S. Sanders, E. Geismar, S. Heilman, and L. Zebehazy. 2006. Summary of Jolly Plateau Salamander data (1997-2006). Report No. SR-07-02, City of Austin Watershed Protection and Development Review Department, Austin, Texas.

Opsahl, S.P. and J.P. Chanton. 2006. Isotopic evidence for methane-based chemosynthesis in the upper Floridan aquifer food web. Oecologia 150:89-96.

Peck, S.B. 1973. Feeding efficiency in the cave salamander, Haideotriton wallacei. International Journal of Speleology 5:15-19.

Petranka, J.W. 1998. Salamanders of the United States and Canada. Smithsonian Institution Press, Washington, D.C.

Poucher, S. 2011. A Field Guide to the Critters of Florida Springs. The National Speleological Society, Huntsville, Alabama.
Poulson, T.L. 1964. Animals in aquatic environments: Animals in caves, pp. 749771. In: D.B. Dill (ed.), Handbook of Physiology, Section 4, Adaptation to the Environment. Williams and Wilkins, Baltimore, Maryland.

Pylka, J.M. and R.D. Warren. 1958. A population of Haideotriton in Florida. Copeia 1958:334-336.

Rachowicz, L.J., R.A. Knapp, J.A.T. Morgan, M.J. Stice, V.T. Vredenburg, J.M. Parker, and C.J. Briggs. 2006. Emerging infectious disease as a proximate cause of amphibian mass mortality. Ecology 87:1671-1683.

Relyea, R.A. 2005a. The lethal impacts of Roundup and predatory stress on six species of North American tadpoles. Archives of Environmental Contamination and Toxicology 48:351-357.

Relyea, R.A. 2005b. The impact of insecticides and herbicides on the biodiversity and productivity of aquatic communities. Ecological Applications 15:618-627.

Relyea, R.A. 2005c. The lethal impact of Roundup on aquatic and terrestrial amphibians. Ecological Applications 15:1118-1124.

Schloegel, L.M., J. Hero, L. Berger, R. Speare, K. McDonald, and P. Daszak. 2006. The decline of the Sharp-snouted Day Frog (Taudactylus acutirostris): The first documented case of extinction by infection in a free-ranging wildlife species? EcoHealth 3:35-40.

Simon, K.S. and A.L. Buikema. 1997. Effects of organic pollution on an Appalachian cave: Changes in macroinvertebrate populations and food supplies. American Midland Naturalist 138:387-401.

Sparling, D.W., G.M. Fellers, and L.L. McConnell. 2001. Pesticides and amphibian population declines in California, USA. Environmental Toxicology and Chemistry 20:1591-1595.

Stuart, S.N., J.S. Chanson, N.A. Cox, B.E. Young, A.S.L. Rodrigues, D.L. Fischman, and R.W. Waller. 2004. Status and trends of amphibian declines and extinctions worldwide. Science 306:1783-1786.

Tercafs, R. 1992. The protection of the subterranean environment. Conservation principles and management tools, pp. 479-524. In: A.I. Comacho (ed.), The Natural History of Biospeleology. Monografias del Museu Nacional de Ciencias Naturales, Madrid, Spain.

USGS (United States Geological Survey). 2005. Pesticides and groundwater (http:// ga.water.usgs.gov/edu/pesticidesgw.html).

Valentine, B.D. 1964. The external morphology of the plethodontid salamander, Haideotriton. Journal of the Ohio Herpetological Society 4:99-102.

Wood, P.J., J. Gunn, and J. Perkins. 2002. The impact of pollution on aquatic invertebrates within a subterranean ecosystem - out of sight out of mind. Archives in Hydrobiology 155:223-237. 